СЕКЦЯ 1

ТЕОРІЯ ТА ІСТОРІЯ СОЦІОЛОГІї

\title{
GLOBALIZATION AS A POSTMODERN PHENOMENON: APPROACHES TO FORMULATION OF THE PROBLEM
}

\author{
ГЛОБАЛІЗАЦІЯ ЯК ПОСТМОДЕРНЕ ЯВИЩЕ: \\ ПІДХОДИ ДО ПОСТАНОВКИ ПРОБЛЕМИ
}

UDC $316.733+316.322$

DOI https://doi.org/10.32843/2663-

5208.2019.9.1

\section{Borodenko O.V.}

$\mathrm{PhD}$. in Philosophy,

Senior Lecturer

at the Department of Sociology

Petro Mohyla Black Sea

National University

\begin{abstract}
The article deals with the process of globalization in the postmodern paradigm. Globalization is assessed as a complex phenomenon of the present, which is not only a decisive direction of world development, but also (and mainly) the objectification of global thinking. The history of the formation of the postmodern theory in sociology is traced not only as a "state of culture", but also as a social and sociocultural phenomenon of the era of globalism, "a special mentality that is widespread in all spheres of human life." The emphasis is placed on the most influential, in our opinion, theoretical developments of postmodern as a social phenomenon, namely: on the definition of J.-F. Lyotard of postmodernism as a "incredulity towards metanarratives", which became the theoretical and methodological basis of the concept of turning from the prevailing macro-level of totality to the values of individual human experience; in the treatment of $F$. Jameson postmodern as a reaction to bourgeois order; on the interpretation of postmodernism as a state of global mentality by Z. Bauman; on the theory of post-industrial society of information type by $D$. Bell. Globalization processes in the world are analyzed as typical postmodern social processes. The mutual influence of globalization and postmodernist tendencies in society and culture can be traced through the analysis of some of the most characteristic phenomena of our time (global decentralization, plurality, simulation process, nomadism). The problem of globalization as a postmodern phenomenon is defined as one of the topical problems of sociology, as well as a promising field of interdisciplinary research.

Key words: globalization, globalization processes, postmodern, global decentralization, plurality, simulation process, nomadism.
\end{abstract}

У статті розглядається процес глобалізації у парадигмі постмодерну. Глобаліза- ція оцінюється як комплексний феномен сучасності, що є не лише визначальним напрямом світового розвитку, але також (i головним чином) об'єктивацією глобального мислення. Простежується на окремих прикладах історія формування сочіологічної теорії постмодерну не лише як «стану культури», але також як соціального й соціокультурного явища епохи глобалізму, «особливого умонастрою, поширеного в усіх сферах людської життєдіяльності». Акцентується увага на найбільш впливових, на наш погляд, теоретичних розробках постмодерну як соціального феномена, а саме: визначенні Ж.-Ф. Ліотаром постмодерну як «недовіри до метанаративів», що стало теоретичним і методологічним підгрунтям концепції повороту від пануючої тотальності макрорівня до цінностей індивідуального досвіду людини; концептуванні Ф. Джеймісоном постмодерну як реакції на буржуазний порядок; трактуванні 3. Бауманом постмодерну як стану глобальної ментальності; теорії постіндустріального суспільства інфрормаційного типу Д. Белла. Глобалізаційні процеси в світі аналізуються як типово постмодерні соціальні процеси. Взаємовплив глобалізації і постмодерністських тендениій в суспільстві та культурі простежується шляхом аналізу деяких найбільш характерних явищ сучасності (глобальна децентралізація, плюральність, симулякризація, номадизм). Проблема глобалізації як постмодерного явища визначається як одна 3 актуальних проблем соціології, а також як перспективне поле досліджень міждисциплінарного характеру.

Ключові слова: глобалізація, глобалізаційн процеси, постмодерн, глобальна децентралізація, плюральність, симулякризація, номадизм.
Setting of the scientific problem. Globalization processes in the modern world and their influence on a person, culture and various types of communities are studied in contemporary sociology from various positions and in various aspects [4, p. 68]. Traditionally, scientists have identified certain areas of globalization as a broad, all-encompassing process: economic, political, cultural globalization, etc. [6, p. 37]. The interaction of globalization and the so-called "postmodern society" is a separate, very prom- ising area of study. At the same time, the postmodern is an unusually wide magnetic field, which has an extremely strong induction and a huge scale of impact. Postmodern is not only the state of our society, but also to a large extent the state of minds, moods and preferences, trends in the socio-cultural sphere. In fact, we live in an era that is largely determined by two trends - globalization and postmodern. Their interaction has been studied far enough. Where do they intersect and complement 
each other? Or maybe these trends contradict one another in some way? These questions, in our opinion, deserve detailed study.

Analysis of the latest research and publications. The problem of globalization as a postmodern phenomenon, as well as the place and role of globalization processes in the postmodern paradigm have been fruitfully studied recently by a number of native and foreign researchers. Since this problem is interdisciplinary in nature, not only sociologists, but also philosophers, cultural scientists, political scientists, and representatives of other sciences turned to its study: Z. Bauman, U. Beck, Y. Boisvert, I. Deviatko, I. Gordeev, S. Huntington, R. Inglehart, G. Lipovetsky, A. Panarin, Yu. Shelistov, and other researchers. Among Ukrainian publications stand out, in particular, the works of I. Alekseenko, M. Cheshkov, V. Gorbatenko, N. Makarenko, A. Postol.

Definition of research objectives. Using materials of publications on this issue, the theoretical conclusions of leading researchers, we will try to characterize some of the most significant, in our opinion, features of globalization as a pronounced postmodern phenomenon. This will give us the opportunity to form a clearer picture of the essence, characteristics and development trends of globalization processes in the first half of the 21st century.

The main objectives of our study: 1) tracing the history of theoretical developments of the concept of postmodern, to distinguish provisions that give us the opportunity to evaluate postmodern as an important social phenomenon; 2) to consider globalization first of all as a direction of thinking, as a special mentality; 3 ) to analyze some of the sign phenomena of the present world, each of which can be considered a joint product of both globalization and postmodern tendencies.

Presentation of the main research material. Traditionally, postmodern is interpreted as the "state of culture" of the late 20th and early 21st centuries, as well as a wide range of trends in world culture and philosophy. The Philosophical Encyclopedic Dictionary of the National Academy of Sciences of Ukraine defines the postmodern as "a) the period of European history, which begins after the completion of the Modern; b) a special mindset, which is now widespread in all spheres of human life: culture, philosophy, politics, economics, techno-sciences, the sphere of planetary communicative praxis, etc." $[9$, p. 501]. So, not only the state of culture and society, but also the special state of minds in a certain epoch - this is what postmodern is.

One of the first definitions of postmodern was given by the French philosopher Jean-François

According to Bell, "a post-industrial society is based on services. Life becomes a game between persons. What counts is not raw muscle power or energy; what counts is information. The central person in this society is the professional, for he is equipped by education and training to provide the kinds of skills which the post-industrial society demands. Central to the post-industrial society is the fact that the sources of innovation are the codifications of theoretical knowledge" [3, p. 576].
Lyotard in The Postmodern Condition: A Report on Knowledge (1979). According to Lyotard, postmodern is above all "incredulity towards metanarratives." [10, p. xxiv]. Lyotard defines the specifics of our era as "post-modernity"; this is "the state of our culture following the transformations which, since the end of the nineteenth century, have altered the game rules for science, literature, and the arts" [10, p. xxiii]. The metanarratives, which previously dominated in the public and everyday consciousness, lost their influence. This inevitably provokes a turn from the totality of the universal to the values of the individual experience, which is formed at the micro level [10, p. 14-17]. As Lyotard notes, "what is new in all of this is that the old poles of attraction represented by nation-states, parties, professions, institutions, and historical traditions are losing their attraction" [10, p. 14]; "each individual is referred to himself. And each of us knows that our self does not amount to much" [10, p. 15].

Other postmodern researchers often emphasize its social essence, as well as the influence that the state of postmodernism has on the nature of social ties in the present world. For example, Fredric Jameson believes that the emergence of postmodern is a protest reaction to the forms of the so-called "high modern", a phenomenon not only cultural, but also a social phenomenon that has become widespread throughout the world: "it is not just another word for the description of a particular style. It is also, at least in my use, a periodizing concept whose function is to correlate the emergence of new formal features in culture with the emergence of a new type of social life and a new economic order-what is often euphemistically called modernization, postindustrial or consumer society, the society of the media or the spectacle, or multinational capitalism" [7, p. 3].

Zygmunt Bauman also emphasizes that the postmodern is one of the most important concepts for understanding the present world and our place in it. Bauman, one of the leading post-modern sociologists, defines this phenomenon as a certain state of mentality and highlights its main characteristics: dynamism, constant fluidity and focus on change; cultural pluralism; relativity of truths; distrust of power structures and any structures in general; domination of the media; symbolism, the predominance of symbols; moral ambivalence [2].

In the context of our research, one cannot but mention the theory of the post-industrial society of the American sociologist Daniel Bell, developed in the 60s of the last century. In fact, the post-industrial society can be called postmodern. According to Bell's definition, post-industrial society is a new type of society, in whose economy not production of goods, but production of services will be a priority. Information and knowledge play a dominant and decisive role in this type of society ${ }^{1}$. 
Let us now consider how the main characteristics of globalization and postmodern overlap with each other on the example of some of the most striking trends in present society.

Global decentralization. What we call global decentralization here is, on the one hand, the most vivid expression of postmodern "incredulity towards metanarratives" and, on the other hand, an expression of the acentrism of the contemporary world. Globalization, we believe, initially contains a very powerful potential of decentralism. If earlier, starting from ancient times and in fact until the middle of the 20th century, the whole world politics, economy and culture were built around one or several dominant centers, strictly observing the rules of world subordination (such centers were Rome, Constantinople, France, England, USA, etc.), the situation has changed in the last decades of the 20th century. In economics, the leading role has shifted to transnational corporations (TNCs), each of which seeks to replace governments and traditional economic and political centers ${ }^{2}$. Global decentralization also takes place in culture, if only because every Internet user has a free and wide choice of cultural product and, for example, if he wants to publish his book at any time or make a film and put it online. The interests and aspirations of a person and communities in the new situation are articulated horizontally rather than vertically. As a result, society acquires an increasingly rhizomorphic character ${ }^{3}$.

Plurality. This property of the present world is directly related to the above. Instead of a single social and cultural monolith, we are currently dealing with a network of a wide variety of practices,

${ }^{2}$ M. Kordos and S. Vojtovic in an analytical article of 2016 cite the following data: "According to information from European Commission (2016) currently multinational corporations are controlling more than of international trade. Today, the number of parent TNCs is about 60000 with about 500000 branches being spread all over the world. Many TNCs today had grown to huge proportions and their annual turnover exceeds the gross national product of most countries. Typical TNC has a high proportion of sales abroad to total sales - often $25 \%$ or more. The number of employees in the largest TNCs consists of several hundreds of thousands - e.g. General Motors in 2015 employed 708,000 workers, Siemens 486,000, Ford Motor 464,000 etc" [8, p. 152].

Rhizome is one of the key postmodern concepts. The term was proposed by J. Deleuze and F. Guattari (1976). The concept expresses a new model of thinking and culture, which is characteristic of the modern era. If in classical European culture, knowledge about the world and the image of the world line up linearly and systematically, then the rhizome lacks both a single principle of construction, a beginning and an end, a "genetic axis", etc. All this resembles the entangled root system of a plant, or rather, the absence of any clear, coherent system.

${ }^{4}$ Virtualization as an all-encompassing trend is evident in almost all areas. For example, scientists who take part in various online conferences and actively use the Internet, only partially work in the real world, and partly their activities are carried out in a virtual environment. The same can be said about modern youth who are "stuck" on social networks, about sociologists who gradually "migrate" to the Internet and about many other groups of the population.

5 "Nomadism, way of life of peoples who do not live continually in the same place but move cyclically or periodically. It is distinguished from migration, which is noncyclic and involves a total change of habitat. Nomadism does not imply unrestricted and undirected wandering; rather, it is based on temporary centres whose stability depends on the availability of food supply and the technology for exploiting it. The term nomad encompasses three general types: nomadic hunters and gatherers, pastoral nomads, and tinker or trader nomads" [11]. ideas and theories. This network is heterogeneous and woven from threads of different material and color. It has tears and gaping in many places. Present global society is nothing more than a territory for various projects and proposals; and it should take some time to make it clear which projects are better than others. In other words, postmodern global society is a field open to social experimentation, a gigantic social mega-experiment.

Simulation as a social trend. In accordance with J. Baudrillard's concept of simulation, our era is characterized by the dominance of myths in human life and society. History and politics become myths. There is an implosion, a collapse of meaning in the mass media. Continuous increase of information does not generate new meanings, but contributes to the birth of new myths and images that are filled with anything. This provokes distrust of the media and the alienation of a large part of society from the media. In the global era, this phenomenon acquires a global character, spreading to the entire planet. "The negative impact of globalization on a person is determined primarily in an attempt to substitute symbols by the codes of mass culture, and the hierarchy of values - a system of simplified stereotypes. This tendency leads to the spread of deviant manifestations on a global scale" [5, p. 7]. In essence, the contemporary global society is becoming less informational and more and more virtual $^{4}$. Simulation takes place in other areas, for example, in politics [1].

Nomadism. In accordance with the nomadological concept of J. Deleuze and F. Guattari (Nomadology, 1986) postmodern society is characterized by a clearly expressed "need for nomadism" 5 . Social space today is interpreted as an acentric space, open to territorialization. The global society is conceived as a rhizome, not a structure, but an open process without beginning and end. In such a society, any social ties may be random. This calls into question the stability of many social institutions.

Conclusions. Globalization, which is increasingly encompassing humanity, is viewed in sociology and other sciences mainly as a process or a combination of social processes. The approach to globalization as a special mentality inherent in a huge number of modern people is, in our opinion, much less studied and, however, very promising.

At the same time, many features that make it possible to define globalization as a postmodern phenomenon are clearly visible. This is, above all, global decentralization as one of the most common phenomena of the present world. In the 21st century, our world is increasingly losing its traditional centers, becoming chaotic and non-systemic, resembling a rhizome. TNCs, mass media and popular culture hits become leaders instead of national states, political and cultural centers in the global era. In addition, 
due to the fall of metanarratives and traditional hierarchies, small localities and virtual space become the main areas of social and cultural life. The postmodern aspect of globalization is sometimes more distinct, and sometimes in latent forms it is revealed in such phenomena as, for example, the radical pluralization of society, simulacrization, nomadism.

\section{REFERENCES:}

1. Baudrillard J. Simulacra and Simulation. In : Selected Writings. Ed. Mark Poster. Stanford : Stanford University Press, 1988, pp. 166-184.

2. Bauman Z. Intimations of Postmodernity. London : Routledge, 1992. 232 p.

3. Bell D. The coming of the post-industrial societ. The Educational Forum. 1976. Issue 40 (4), pp. 574-579. doi: 10.1080/00131727609336501

4. Borodenko O.V. Cultural aspects of globalization : the basic theoretical and methodological positions [Kulturni aspekty hlobalizatsii : osnovni teoretyko-metodolohichni pozytsii]. Scientific works SWorld. Issue 48. Vol. 2. Ivanovo : Nauchnyiy mir, 2017, pp. 67-69.

5. Borodenko O.V. Deviancy in the time of globalism : some theoretical- methodological aspects [Deviantnist doby hlobalizmu : deiaki teoretyko-metodolohichni aspekty]. Habitus : Scientific journal. 2017. Issue 4, pp. 4-7.

6. Borodenko O.V. "Globalization" - "integration" "globalism" : to the question of necessity for overcoming terminological and content contradictions ["Hlobalizatsiia" - "intehratsiia" - "hlobalizm" : do pytannia pro neobkhidnist usunennia terminolohichnykh i zmistovnykh rozbizhnostei]. Scientific World Journal. Minsk : Yolnat PE, 2017. Issue 15. Vol. 4, pp. 35-38.

7. Jameson F. Postmodernism and Consumer Society. In : The Cultural Turn. Selected Writings on the Postmodern, 1983-1998. London - New York : Verso, 1998, pp. 1-20.

8. Kordos M. and Vojtovic S. Transnational corporations in the global world economic environment. Procedia - Social and Behavioral Sciences. 2016. № 230, pp. 150-158.

9. Lukianets V. Postmodern. Philosophical Encyclopedia Dictionary [Filosofskyi entsyklopedychnyi slovnyk]. The National Academy of Sciences of Ukraine. H.S. Skovoroda Institute of Philosophy. Kyiv : Abrys, 2002. 744 p.

10. Lyotard J.F. The Postmodern Condition : A Report on Knowledge. Trans. G. Bennington and B. Massumi. Minneapolis : University of Minnesota Press, 1984.

11. "Nomadism". Available at : https:// www.britannica.com/topic/nomadism. 